\title{
The Use of Audio-Visual Materials as Strategies to Enhance Speaking Skills among ESL Young Learners
}

\author{
Keetha Kathirvel, Harwati Hashim* \\ Faculty of Education, Universiti Kebangsaan Malaysia, Bangi, Malaysia \\ Email: ^harwati@ukm.edu.my
}

How to cite this paper: Kathirvel, K., \& Hashim, H. (2020). The Use of AudioVisual Materials as Strategies to Enhance Speaking Skills among ESL Young Learners. Creative Education, 11, 2599-2608. https://doi.org/10.4236/ce.2020.1112192

Received: October 28, 2020

Accepted: December 8, 2020

Published: December 11, 2020

Copyright ( 2020 by author(s) and Scientific Research Publishing Inc. This work is licensed under the Creative Commons Attribution International License (CC BY 4.0).

http://creativecommons.org/licenses/by/4.0/

\section{(c) (i) Open Access}

\begin{abstract}
There are four main skills in English language namely listening, speaking, reading and writing respectively. Speaking skills is considered the most essential skills as it helps the learners to communicate with others effectively. Some of the factors that contributing to the low level of speaking skills are lack of exposure, low confidence level, and high level of anxiety towards English Language. Thus, these issues should be addressed in order to enhance ESL learners' speaking skills. In this $21^{\text {st }}$-century learning and teaching, various strategies involving ICT have been invented by teachers to improve speaking skills among ESL learners. One of the strategies is the use of audio-visual materials to enhance speaking skills. An audio-visual material is a technology-based strategy that has gotten many positive results from the ESL learners. Therefore, it is believed that this strategy would develop speaking skills among ESL learners. Hence, this paper explains how audio-visual materials assist in improving speaking skills and the benefits of using audio-visual materials.
\end{abstract}

\section{Keywords}

Learning Strategies, Audio-Visual Materials, ESL Learners, Speaking Skills

\section{Introduction}

Technology is ruling our world and doing many wonders in human life. Aligning with the invasion of the Fourth Industrial Revolution, technologies are rapidly advancing in various industries, and the educational field is not exempted from embedding technology in its sector (Mudin, Eng, Rahman, Ibrahim, \& Jopony, 2018: p. 3). Larsen-Freeman \& Anderson (2011) supported the idea that technology affords teaching materials and creates exciting learning experience to 
the world of learners. Through the use of technology, learners can be motivated to master all the four language skills (Yunus et al., 2010; Hashim, 2018; Mohamad et al., 2018; Rafiq \& Hashim, 2018; Hashim et al., 2018). According to Zaremba (2006), speaking appears to be the most essential skill required for communication among four macro English skills. Therefore, it needs to be given more important as it serves many purposes in everyone's life.

Supiyati (2011) stated that practically the use of audio-visual materials is one of the suitable techniques in developing speaking skills of students. It has given many positive outcomes in students' speaking skills. Harmer (2007) also states that if speakers want master to speak effortlessly in English, they need to be able to correctly pronounce phonemes, use proper stress and intonation patterns and speak in connected speech. For that, they need to see and hear someone pronounce the phonemes correctly so that they can imitate it easily. In this case, audio-visual materials have been a great facilitator in helping the learners.

In Malaysian Education System, a new curriculum which is Common European Framework of Reference (CEFR) has been used since the year 2017. More attention has been given to speaking skill whereas it is evaluated by teachers in daily teaching and learning session unlike in the previous curriculum. Therefore, audio-visual materials are believed to support learners in speaking. The following sections discuss the speaking skills among ELS learners, various related research done using audio-visual materials and the potential affordances and the constraints of the use of audio-visual materials among ESL learners.

\section{Speaking Skills among ESL Learners}

Speaking is a fundamental skill that needed to be acquired by language learners. It is very crucial for communicating. Without it, it is very tough to survive in the world that full of evolving technologies in which English is considered as the primary language to communicate. According to Chaney \& Burk (1998), speaking is "the process of building and sharing meaning in a variety of contexts using verbal and nonverbal signs". Whereas, Burns \& Joyce (1997) have said that speaking is an interactive process of building meaning that includes constructing and receiving and processing information. O'Malley \& Chamot (1990: pp. 66-67) define speaking as an example of a dynamic cognitive capacity that can be distinguished into many hierarchal sub-skills, some of which might need controlled processing while others just automated processing. According to Ur (1996), speaking is the most vital skill among four skills which are listening, speaking, reading, and writing as a person who recognizes a language is called to as "speaker of that language". All in all, speaking skills is essential in expressing our thoughts, opinions, feelings and messages to each other.

Looking into the Malaysian context, most ESL learners are not good in speaking due to little exposure to the language, especially outside the classroom $(\mathrm{Mu}-$ sa, Koo, \& Azman, 2012). Speaking skills has always been a skill that unnoticed by teachers because of the difficulty in teaching it. It is supported by Hassan \& 
Selamat (2002), who stated that teaching communicative competences such as speaking and listening are often overlooked by Malaysian teachers. In fact, according to Samad, Hussin, \& Sulaiman (2015), they agreed that Malaysian public standardized assessments only concentrate on reading and writing rather than listening and speaking. The standardized examinations show that evaluation is very examination-oriented in the Malaysian context, resulting in pupils becoming passive recipients in the classroom (Chan \& Sidhu, 2010). People tend to forget that we are living at a time when the capability to speak English effortlessly has become an essential, particularly those who want to advance in certain areas of human endeavor (Al-Sibai, 2004). However, equal importance has started to give to speaking skills same as other skills after the implementation of a new curriculum, which is Common European Framework of Reference (CEFR) since the year 2017. Therefore, a suitable approach and teaching technique must be applied to improve the skill as Shaimaa (2006) stressed that speaking ability remains a far-fetched target or an undefined subject believed to be impossible to achieve by pupils like other skills.

\section{Various Related Research Done Using Audio-Visual Materials and the Potential Affordances}

Audio-visual materials are one of the teaching and learning tools which have been used by teachers to create a technology-based classroom. It helps both teacher and students in their everyday teaching and learning process. There are many definitions have been provided by scholars and writers about audio-visual materials as cited in Guterres \& Quintas (2018). Kinder S. James (2002) stated that audio-visual materials are any device which can turn the learning experience more concrete, more realistic and more dynamic. According to Riri (2011), audio-visual materials are recording tools for improving speaking skills that are used multiple times and more than others. On the other hand, Francis (2011) defines the term audio-visual materials are generally used to refer to those instructional materials which can be used to express meaning without relying on verbal symbols or language. In short, audio-visual materials are an interactive tool with the combination of text, image, sound and video.

Various related researches have been conducted using audio-visual materials among learners to improve language learning. Many studies showed that they improve teaching capacity, free the overworked classrooms and provide teachers with a practical approach to speaking skills training (Umar, 2014). Similarly, an interesting study was conducted to get to know the Pakistani's University students insightful on the use of audio-visual materials by Ghazala Kausar (2013). The result of the study showed that they could learn effortlessly with the support of audio-visual materials. They indicated that, by recalling the situation from when they had heard or seen it, they would quickly remember new words. It receives support from Natoli (2011) who emphasized that audio-visual materials are essential in teaching and learning processes because "having seen something, most people recognize, for whatever it was, it creates an image with the mere 
mention and can be freely spoken about." Another research was conducted specifically on improving speaking skills among second-grade students of Ensino Secundariu Cristal in the school year 2017 using audio-visual materials by Charles Fatima Guterres (2018). The result of the research revealed that audio-visual tool was the successful way, and it improves students' speaking skills. The researcher added that this method helped in encouraging the students to develop their speaking ability as well.

A study by Albahiri \& Alhaj (2020) was conducted to explore the elements in the stimulation of speaking skills among second language learners. The focus of the study is mainly on the theories related to technology-aided language lessons and media elements that encourage learners to interact and communicate effectively. The researchers focused on YouTube as a source to provide videos that will function as aids. A quasi-experimental research was conducted where 48 students from a higher learning institute in Saudi Arabia had been used as participants. The research showed that the visual elements in videos played a very significant role in encouraging second language learners to be more interested in interacting using the language. Specifically, YouTube was found to be a very valuable source that provided a multitude of visual and audio materials that aided meaningful interactions.

Besides, Yunus et al. (2018) conducted a study to investigate the use of authentic English video clips among EFL students in Aceh, Indonesia. The study, which was a quasi-experimental study used non-randomised groups to conduct the experiments. 68 students from a high school in Banda Aceh took part in the study. For the experimental group, authentic video clips were used in their lessons and for the controlled group, they used audio compact discs. The core idea of the research was to further analyse the effectiveness of audio-only materials and audio-visual materials. The researcher noted that, there were positive effects in both the groups as both groups showed improvements. However, higher t-test result of the experimental group only further affirmed that the use of videos was more effective compared to audio. This is crucial in understanding how audio and visual both work hand in hand to create a more effective learning environment in the language classroom.

Apart from that, Cakir (2006) said that everyone knew very well that audiovisual materials are a great helper in stimulating and facilitating the foreign language learning process. According to him, students show more interest in language class with the use of audio-visual materials as it encourages them to stay focus, and they can relate their learning with their real life. He also added that, recently, the use of video in English classes had overgrown because of the increasing stress on communicative techniques. Moreover, Hariyanto (1995) in Ramendra \& Ratminingsih (2007) stated audio-visual materials are enticing tools for learners' eyes and ear that can be used to help teachers to educate the students. Subartha (2012) shared the same view which she said that films have a dominant influence on pupils as they appeal not only to the eyes and ears but 
also to the emotions, which is the correct platform in building the right attitudes and habits.

Additionally, another researcher Madhuri (2013), emphasized that audio-visual materials are the only methods which can help students in improving their speaking skills among other techniques. He said audio-visual materials support the sound and sight in teaching by enabling more than one sensory channel to promote student learning. Kausar (2013) in Thaseem \& Kareema (2017) presented that it is very important to use audio-visual materials for learning English. It is because the students encounter many problems in mastering the English language and feel it is hard to learn the English language without the help of any audio or visual materials. It increases the amount of emotional input, the level and the productivity of verbal skills of a person (Tarcan, 2004). Supporting the point of view of the uncountable advantages of audio-visual materials, Umar (2014) claimed that the use of high-tech new technology as audio-visual materials encourages the unwilling English learners to practice speaking regularly.

\section{The Constraints of Using Audio-Visual Materials among ESL Learners}

It has become ubiquitous nowadays to see technology-based classroom everywhere as it involves a variety of language learning activities. It is a well-known truth that technology and interaction of teaching and learning are inseparable, where teachers should choose suitable technologies for their teaching-learning situations to aid their learners to learn well (Ismail, 2006). However, there are few constraints of using it in the classroom by teachers. First and foremost, most teachers find it time-consuming as they need to search for appropriate audiovisual materials that aligning with the textbook content they are teaching. A research was carried out to investigate factors affecting English as a Foreign Language teachers use of technological aids in the classroom in Korea by Park \& Son (2009). This study reports that it takes up teachers' time to find suitable on-line EFL resources and integrate with textbooks in order to meet the levels and needs of students.

Furthermore, in another study which was conducted by Maniruzzaman \& Rahman (2008) had suggested few things on the use of audio aids in the EFL class at the tertiary level in Bangladesh. They said that insufficient of teacher training, inefficiency of audio tools and material, and the administrative indifference hinder the use of audio aids in the EFL class. They further added that foreign language learners show passiveness or disappointment with EFL course materials when they find it unfamiliar, hard, tricky, mechanical and unappealing. Besides, Jadal (2011) conducted a study at primary Level in Z.P Primary Schools of Solapur District, India on the effectiveness of the audio-visual aids in teaching and learning of English. Findings of the study recommend that many English teachers were found incompetent to use audio-visual and materials. These teachers were not entirely conscious of the countless projected aids to be used in the classroom. 
Adding to that, Dias (1999) argue that to make technology essential to their teaching, language teachers and their administrators must aware common obstacles to technology integration and be ready for the changes caused by the integration of technology. According to Dias, the ultimate task for EFL teachers is using technology to bring innovative learning opportunities for students. Thus, looking into all the constraints above, teachers have to be prepared and ready to overcome all the challenges that they might encounter with the use of audiovisual materials to provide effective teaching to the students.

\section{Pedagogical Implications}

The affordances of audio-visual materials in enhancing speaking skills has overtaken the constraints as discussed above. It can be seen clearly that the use of audio-visual materials helps students in improving their speaking skills. They can see and hear the words which could help them to remember better when speaking. They can pronounce it correctly as they already hear the correct pronunciation from the audio before they talk. It indirectly would boost their confidence level in speaking, and they can overcome their shyness as well. Apart from that, it helps in creating $21^{\text {st }}$-century learning where more emphasis is given on the use of ICT. Learners will feel motivated to learn as most of the learners are technology savvy nowadays.

However, teachers should take into consideration the listed constraints above to aid the students in speaking. In this case, the help of other parties, such as school administration is very crucial. School administration should make sure the classrooms are well equipped with internet connection and technologies for the teachers to use audio-visual materials without any troubles, especially in rural areas. Pupils from rural areas should not be neglected as they have equal rights in experiencing the learning process the same as other students. Thus, the school administration must take necessary steps to overcome these problems such as by providing downloaded audio-visual materials which are not required internet connection during the teaching and learning process. The teachers can use it anytime without the need of internet connection which would lessen the burden of teachers in finding audio-visual materials.

Besides, the teachers should be given enough training on the use of technology in teaching and learning to make it exciting and interactive. It is crucial to create awareness among teachers on the use of audio-visual materials. It is also would help to break the traditional method of teaching by some of the teachers who do not bother in integrating technologies in their daily teaching and learning. Courses and training would be an eye-opener for them to change the way they are teaching based on $21^{\text {st }}$-century learning environment. Apart from that, choosing the right audio-visual materials are essential as well to suit the students' level and the content that they are going to teach. For that, teachers can collaborate with their colleagues to choose the best materials for the students.

Moreover, most ESL teachers tend to ignore the significance of using audio in their classroom, where more attention is given to the video. They did not focus 
on the pronunciation and the words used by the speaker in the audio to improve the students' speaking skills. The teachers choose a video with eye-catching visuals for learners to attract them rather than focusing on the pronunciation as well as the vocabularies used in the video. It is established in recent studies on technology integration into teacher education curricula that the video has received growing attention (Ozkan, 2002: p. 1). More researches have done as well on the use of video compared to audio in language teaching.

In a nutshell, the audio-visual materials have the power to turn a dull classroom into a fun and interactive atmosphere. Ranasinghe \& Leisher (2009) point out that technology can never substitute the human mind, but it can help to develop it. Thus, the effective use of audio-visual materials can produce a right user of the second language without a doubt.

\section{Conclusion}

As we all aware, our education system is emphasizing to create $21^{\text {st }}$-century learning aligning with the aim of our National Philosophy of Malaysian Education (NPME) which is to produce a holistic individual through the implementation of 21st-century learning (Ministry of Education, 2015: pp. 1-10). In line with that, audio-visual materials have been contributing a lot to both teachers and students in language learning, especially in improving speaking skills as stated above. It creates an interactive, fun and most importantly, effective education to students. Moreover, with this COVID-19 outbreak which has been declared as pandemic many countries have opted to online learning. Malaysia too has started this online learning after the implementation of Movement Control Order (MCO) which required the closing of all educational institutions. Thus, audio-visual materials have become a great helper for teachers to teach students from home and for students to understand the lesson better. For further research, it is recommended to do more research on the use of audio-visual materials in enhancing speaking skills to give more insight to teachers since most ESL learners have problems in speaking skills. For example, teaching and learning activities that can be done through this method, the criteria to be considered when selecting audio-visual materials could be given more focus for the upcoming research.

\section{Acknowledgements}

The authors would like to thank Universiti Kebangsaan Malaysia under the Research Grant number (i) KRA-2018-044 and (ii) GGPM-2019-037 for supporting this project.

\section{Conflicts of Interest}

The authors declare no conflicts of interest regarding the publication of this paper.

\section{References}

Albahiri, M. H., \& Alhaj, A. A. M. (2020). Role of Visual Element in Spoken English Dis- 
course: Implications for YouTube Technology in EFL Classrooms. The Electronic Library, 38, 531-544. https://doi.org/10.1108/EL-07-2019-0172

Al-Sibai, D. (2004). Promoting Oral Fluency of Second Language Learners: Educational Linguistics. Riyadh: King Saud University.

Burns, A., \& Joyce, H. (1997). Focus on Speaking. Sydney: National Center for English Language Teaching and Research.

Cakir, I. (2006). The Use of Video as an Audio-Visual Material in Foreign Language Teaching Classrooms. The Turkish Online Journal of Educational Technology, 5, 67-72.

Chaney, A. L., \& Burk, T. L. (1998). Teaching Oral Communication in Grades K-8. Boston, MA: Allyn \& Bacon.

Dias, L. B. (1999). Integrating Technology. Learning and Leading with Technology, 27, 10-21.

Francis, A. (2011). Library Experts Speaks on Audio-Visual Material. Lafia: United Nations Educational, Scientific and Cultured Organization (UNESCO), World Day for Audio-Visual Heritage.

Guterres, C. F., \& Quintas, L. (2018). Using Audio Visual Tool to Develop Speaking Skill to the Second Grade Students of Ensino Secundariu Cristal in the School Year 2017. ISCE: Journal of Innovative Studies on Character and Education, 2, 31-43.

Harmer, J. (2007). The Practice of English Language Teaching. New York: Longman.

Hashim, H. (2018). Application of Technology in the Digital Era Education. International Journal of Research in Counseling and Education, 2, 1-5. https://doi.org/10.24036/002za0002

Hashim, H., Yunus, M. M., \& Embi, M. A. (2018). Learning through Mobile: Exploring the Views of Polytechnic ESL Learners. Teaching and Learning English in Multicultural Contexts (TLEMC), 2.

Hassan, F., \& Selamat, N. F. (2002). Why Aren't Students Proficient in ESL: The Teachers' Perspective. The English Teacher, 31, 107-123. http://journals.melta.org.my/index.php/tet/article/view/362/252

Ismail, C. (2006). The Use of Audio as an Audiovisual Material in Foreign Language Classroom. Turkish Online Journal of Educational Technology, 5, 67-72.

Jadal, M. M. (2011). A Study of Effectiveness of the Audio-Visual-Aids in Teaching and Learning of English at Primary Level in Z.P. Primary Schools of Solapur District. Indian Streams Research Journal, 1. http://journals.melta.org.my/index.php/tet/article/view/362

Kausar, G. (2013). Students' Perspective of the Use of Audio Visual Aids in Pakistan. International Proceedings of Economics Development and Research, Vol. 68, 11.

Larsen-Freeman, D., \& Anderson, M. (2011). Techniques and Principles in Language Teaching. Oxford: OUP.

Madhuri, J. N. (2013). Use of Audio Visual Aids in Teaching and Speaking. Research Journal of English Language and Literature, 1, 108-122.

Maniruzzaman, M., \& Rahman, M. M. (2008). The Use of Audio Aids in the EFL Class at the Tertiary Level: A Plus or a Minus? Daffodil University International Journal of Business and Economics, 3, 121-137.

Ministry of Education (2015). Executive Summary Malaysia Education 2015-2025 (Higher Education).

Mohamad, M., Ghazali, N., \& Hashim, H. (2018). Secondary School Students' Perceptions on the Use of Google+ towards Improving ESL Writing Skills. International Journal of Emerging Technologies in Learning (iJET), 13, 224-238. 
https://doi.org/10.3991/ijet.v13i09.8479

Mudin, D. K. D., Eng, H. S., Rahman, M., Ibrahim, P., \& Jopony, M. (2018). Industrial Revolution 4.0: Universiti Malaysia Sabah Perspective. E3S Web of Conferences, 48, Article No. 03005. https://doi.org/10.1051/e3sconf/20184803005

Musa, N. C., Koo, Y. L., \& Azman, H. (2012). Exploring English Language Learning and Teaching in Malaysia. GEMA Online ${ }^{\mathrm{mx}}$ Journal of Language Studies, 12, 35-51.

Natoli, C. (2011). The Importance of Audio-Visual Materials in Teaching and Learning.

O’Malley, J. M., \& Chamot, A. U. (1990). Learning Strategies in Second Language Acquisition. Cambridge: Cambridge University Press. https://doi.org/10.1017/CBO9781139524490

Ozkan, B. (2002). The Use of Video Cases in Teacher Education. TOJET: The Turkish Online Journal of Educational Technology, 1.

Park, C. N., \& Son, J.-B. (2009). Implementing Computer-Assisted Language Learning in the EFL Classroom: Teachers' Perceptions and Perspectives. International Journal of Pedagogies and Learning, 5, 80-101. https://doi.org/10.5172/ijpl.5.2.80

Rafiq, K. R. M., \& Hashim, H. (2018). Augmented Reality Game (ARG), 21st Century Skills and ESL Classroom. Journal of Educational and Learning Studies, 1, 29-34. https://doi.org/10.32698/0232

Ramendra, D. P., \& Ratminigsih (2007). Pemanfaatan Audio Visual Aids (AVA) dalam Proses Belajar Mengajar Mata Pelajaran Bahasa Inggris di Sekolah Dasar. Jurnal Penelitian dan Pengembangan Pendidikan, 1, 79-95. http://www.infodiknas.com/wp-content/uploads/2014/12/PEMANFAATAN-AUDIOVISUAL-AIDS-AVA-DALAM-PROSES-BELAJAR-MENGAJAR-MATA-PELAJARA N-BAHASA-INGGRIS-DI-SEKOLAH-DASA.pdf

Ranasinghe, A. I., \& Leisher, D. (2009). The Benefit of Integrating Technology into the Classroom. International Mathematical Forum, 4, 1955-1961.

Riri, I. S. (2011). Teaching Speaking through Audio Visual Aids. Bogor.

Samad, A. A., Hussin, H., \& Sulaiman, T. (2015). Developing a Portfolio Assessment Model for the Teaching and Learning of English in Malaysian L2 Classroom. English Language Teaching, 8, 164. https://doi.org/10.5539/elt.v8n7p164

Shaimaa, A. (2006). The Effectiveness of a Task-Based Instruction Program in Developing the English Language Speaking Skills of Secondary Stage Students (pp. 1-254).

Subartha, P. (2012). The Audio-Visual Aids in English Teaching. National Conference on Developing Scenario in Applied Science and Communicative English, Coimbatore. http://codebreakerskct.site50.net/conference/assets/pdf/English/14.pdf

Supiyati, D. Y. A. H. (2011). Improving Students' Speaking Skills by Using Audio-Visual Aids in Class IA RSBI SD N Cemara Dua No. 13 Surakarta in 2009/2010 Academic Year. Unpublished Undergraduate Thesis, Surakarta: Teacher Training and Education Faculty, Sebelas Maret University.

Tarcan, A. (2004). Yabancı dil öğretim teknikleri. Ankara: Nobel, 2004.

Thaseem, W., \& Kareema, M. I. F. (2017). Implication of Multimedia Audio-Visual Aids in the English Language Classroom. 7th International Symposium 2017, 7-8 December 2017.

https://www.researchgate.net/publication/322499103 Implication Of Multimedia Au diovisual Aids in the English Language Classroom/download

Umar, F. (2014). Audio Visual Aids in Education, Definition, Types and Objectives. MIER University Press.

Ur, P. (1996). A Course in Language Teaching, Practice and Theory. Cambridge: Cam- 
bridge University Press.

Yunus, M. M. et al. (2018). The Influence of Authentic English Video Clips on Students' Listening Comprehension. The New Educational Review, 53, 105-114. https://doi.org/10.15804/tner.2018.53.3.09

Yunus, M. M., Hashim, H., Embi, M. A., \& Lubis, M. A. (2010). The Utilization of ICT in the Teaching and Learning of English: "Tell Me More". Procedia-Social and Behavioral Sciences, 9, 685-691. https://doi.org/10.1016/j.sbspro.2010.12.218

Zaremba, A. J. (2006). Speaking Professionally. Thompson South-Western. 